vol. 33 - $n^{\circ} 2$ et $3 \mid 2017$

Dire la violence des frontières. Mises en mots de la migration vers l'Europe

\title{
Muslim Women's Political Engagement in British and French Society
}

L'engagement politique des femmes de culture musulmane en France et en Grande-Bretagne

El compromiso político de las mujeres musulmanas en Francia y Gran Bretaña

Danièle Joly

\section{(2) OpenEdition}

Journals

Electronic version

URL: https://journals.openedition.org/remi/8643

DOI: 10.4000/remi.8643

ISSN: $1777-5418$

Publisher

Université de Poitiers

\section{Printed version}

Date of publication: 1 September 2017

Number of pages: 157-181

ISBN: 979-10-90426-59-7

ISSN: 0765-0752

Electronic reference

Danièle Joly, "Muslim Women's Political Engagement in British and French Society", Revue européenne des migrations internationales [Online], vol. 33 - n² et 3 | 2017, Online since 01 September 2019, connection on 14 April 2022. URL: http://journals.openedition.org/remi/8643 ; DOI: https://doi.org/ 10.4000/remi.8643 


\section{Muslim Women's Political Engagement in British and French Society}

\section{Danièle Joly ${ }^{1}$}

\section{Introduction}

This article addresses the participation of women from Muslim communities in civic and political life in Britain and France. It establishes the key features of the societal frameworks which have surrounded these women in the two countries since World War II and pays particular attention to dimensions informed by racism and anti-Muslim prejudice. It interrogates the interaction of the women with majority society, the obstacles and enablements they identify and the impact those may have on their participation in the public sphere, on their civic and political engagement.

\section{Framework of the Research}

The conceptual framework of our research draws on Archer's social realism (1995) and Touraine's sociological intervention (SI) (1973 and 1978). Following Archer's approach, the women are situated within a structural and cultural environment which is not of their making and creates a set of constraints and enablements wherein they develop their action (Archer, 1995). However, the influence of this environment is not deterministic because they are subjects and actors of their own life (Archer, 2007). Hence the choice of Touraine's methodology which relies on the social actors' capacity to analyse their own experience with the researchers, as is explored through SI (Touraine, 1973 and 1978; Dubet and Wieviorka, 1996). The women's environment is articulated as three large interconnecting sets: the women's immediate circle composed of family and community; the Muslim group; and wider British and French society within which they also evolve. This article focusses on Muslim women's interaction with majority society, from the vantage point of the women themselves in the light of a feminist approach.

This article draws on a large comparative project on France and Britain concerning the civic and political participation of women from Muslim commu-

\footnotetext{
1 Émeritus Professor, Department of Sociology, University of Warwick (UK), Collège d'Études mondiales MSH Paris, CADIS, EHESS, Paris; d.s.joly@warwick.ac.uk
} 
nities. ${ }^{2}$ The empirical research included: a register of 100 associations derived from primary material, internet sites, telephone calls and visits to associations; forty in-depth, semi-structured interviews with women in positions of influence in associations, campaigns, politics, education, media, etc.; forty interviews with women without such a high profile; twenty direct observations in associations; a questionnaire conducted face-to-face with 226 women (adapted, with IpsosMORI's permission, from their annual Audit of Political Engagement) and SI groups. We found our informants in mosques, associations, political parties and through snowballing among our contacts from previous research. Our empirical research was held mostly in Birmingham and Coventry with secondary sites in Bradford, Cardiff, London Manchester, Glasgow and Rotherham (for Britain) and for France, in Paris, the Île de France region, Lyon and satellite towns. The empirical data for this article was largely drawn from SI and interviews. The women from Muslim communities who are the subjects of this study are strictly women whose family origin lie in Muslim majority countries whether it be in Asia, the Middle East, Africa or any other part of the world, whatever their degree of practice and belief, including atheists or agnostics; Muslim communities in Britain and France being considered as a sociological category in this piece of research (Bowen et al., 2014: 4). ${ }^{3}$ These women are thereafter called Muslim women in this article.

Given our emphasis on the women's own analysis of their situation and their capacity of action, SI was particularly pertinent for this piece of research. Although $\mathrm{SI}$ is well established and has been widely applied in French sociology, it had only been used previously in the UK by the author of this article (in Blacks and Britannity, 2001). As a methodology, SI derives from a specific theory of social action developed by Touraine (1973), primarily for the study of social movements: in Touraine's view, social action is meaningful and subjectively oriented by responses to a situation because it is defined by the social actors' commitment to values, principles and rules. Moreover, social action cannot be separated from the social relations within which it is produced (Dubet, 1999). ${ }^{4}$

"Sociological intervention starts from the idea that the nature of a collective behaviour can be best known by interpreting the work performed by a group of actors as the group analyses its own actions under conditions created by researchers and managed by both parties." (Touraine, 1978: 296)

2This article is based on an ESRC funded research project: Danièle Joly and Khursheed Wadia, Women from Muslim Communities and Politics in Britain and France, Award Ref: RES-062-23-0380. My thanks go to the MSH and the CADIS and in particular to Alexandra Poli and Giulia Fabbiano. What is put forward regarding Muslim women in this article is based on our empirical research except when indicated otherwise.

3 Although a good proportion of the women involved in the qualitative part of the research were of modest family background, most had a reasonable or high degree of education, either acquired in Britain or prior to migration. The design and the funding of the project did not permit to include a good sample of women of modest background with a low level of education for a variety of reasons including language barriers. Those women suffer from the same type of gender disadvantage as shown for non-Muslim, working class women (Christy, 1994: 36-37; Allwood and Wadia, 2000).

4 For a more detailed account of the Sociological Intervention method in relation to this research, see Joly (2016). 
The method evolved subsequently, in particular with Dubet's and Wieviorka's research, to investigate experience and the capacity of individual and collective action, through a notion developed by Touraine himself, the capacity of subjectivation (Touraine, 2013). This method presupposes that actors can know what they are doing and see through ideologies and the spontaneous categories of practices (Dubet and Wieviorka, 1996) and it also encourages the subjects' self-reflexivity. It is grounded on the notion that a debate between actors and researchers within set conditions can produce knowledge, working on what is said, the group's history and the analyses developed during discussions. In Britain, two SI groups (one in Birmingham and one in Coventry) were formed for the purpose of this research. We aimed to bring together as diverse a group as possible which reflected the characteristics of Muslim women in Britain. In Birmingham the group included mostly married women and women who were or had been in employment but subsequently became mothers/home-makers. The sociological intervention in Coventry involved mostly young women from different regions of Britain, students (some of whom were part-time and also worked), single women barring one who had been married (and had divorced). While the groups were not a statistically representative sample, we took into account Muslim women's ethnicity, country of origin, nationality, branch of Islam, residence status, marital status and age. The groups included women with family origins in Pakistan (Punjab and Azad Kashmir), Bangladesh, India, Tanzania, Nigeria, Algeria, Bosnia, Turkey, and Iraqi Kurdistan. Two of them were refugees from Iraqi Kurdistan and from Bosnia. The largest proportion originated from the Indian subcontinent reflecting the majority component of Muslims in Britain. The groups met weekly with the researchers over several weeks: thirteen weeks in the case of the Birmingham group and five in the case of the Coventry group. This included sessions with invited interlocutors and closed sessions during which analysis took place. It is worth noting that after the conclusion of the sociological intervention in Birmingham, the group requested that we continued to meet a couple of times a year as a follow up. This took place over four years and provided an opportunity to gain updates on developments in the women's life and on their views of topical political issues, thus enriching our knowledge of their engagement.

In France, four focus groups (of six, twelve, five and seven participants respectively) met separately, each comprising a different group of women but which nevertheless reflected the variety of national origins, generations, social occupations and key branches of Islam found among Muslim communities in France. They included women with family origins in Algeria, Morocco, Tunisia, Mali, Guinea-Conakry and Turkey. ${ }^{5}$ Some were first generation migrants whilst the majority were born or brought up in France since a young age and a few were refugees who had fled Algeria at the time of the civil war. Key themes put forward by the researchers were debated together by the group and the researchers. Although each of the Paris focus groups met once, the sessions lasted four to five hours while the last group acted as a "plenary" group bringing together participants from the first three. The length of the sessions also gave participants the opportunity to set the agenda in accordance with the discussion

5 The sample of women interviewed in France and Britain comprised additional countries of origin over and above those quoted for the SI. 
themes suggested by the researchers and to offer analysis at the end of the discussion. The groups' organisation and activity therefore ensured the involvement of the women in discussions of issues based upon their lived experiences and understanding, and hence in the very analysis of their situation; in line with the SI approach and also the aim of feminist research to break down hierarchies between researchers and researched subjects and involve the latter in achieving research objectives.

France and Britain offer good comparative sites for our investigation because they display both similarities and differences in their political histories, cultures and institutions. They also provide good terrains for the study of Muslim women's political participation. Indeed, both Britain and France have extended histories of immigration linked to their colonial past which have led to the settlement of large Muslim populations. The two countries display different approaches to issues of immigration and integration, in the shape of multiculturalism versus republican universalism respectively. The French state is based on secularist principles which have been enhanced since 1989 while in Britain, the nonseparation of state and church is testified by an Established Church. In addition, attitudes and policies regarding women and the feminist movement have developed in a differentiated manner in the two countries. However, our aim was not merely to depict the contrasting situations surrounding Muslim women in the two countries but to embrace a wider scope. In the first instance, the comparison makes it possible to attain some generalisation since the quandary faced by Muslim women in France and Britain shares some common features that are echoed throughout the western world as Islam has been thrown into the spotlight the world over. Secondly, our focus was the women themselves and how they constructed themselves as actors analysing and negotiating obstacles and enablements in both countries.

A vast literature was called upon for the purpose of this investigation. Societal frameworks in France and Britain drew on the numerous pieces of research carried out by other authors and previous research from the leaders of the ESRC research project. In the first post-World War II decades, researchers in Britain dwelt on race relations and ethnic relations, racism and multiculturalism while in France they examined "immigrés" and "Arabs", racism and integration. 6 Research on immigrant women came at a later date and primarily dealt with education and employment. The question of Muslims and their interaction with and participation in majority society emerged in research at the end of the 1980s in Britain and France and became increasingly substantial. ${ }^{7}$ However, regarding women of Muslim background, literature has tended to concentrate on participa-

6 Such as Banton (1967); Bertossi (2001); Bertossi and Duyvendak (2012); Candappa and Joly (1994); Daniel (1968); Dubet (1987); Dubet and Lapeyronnie (1992); Hall et al. (1978); Jenkins (1997); Joly (2001 and 2007); Lapeyronnie (1993); Miles and Phizaclea (1984); Modood and Werbner (1997); Parekh (2000); Patterson (1968); Rex (1988); Rex and Drury (1994); Rex and Moore (1967); Rex et al. (1987); Rex and Tomlinson (1979); Solomos (1986); Wieviorka (2001).

7 Such as Amiraux (2002); Baubérot (2000); Beckford et al. (2005); Bowen (2004); Boyer (1998); Cesari (1998); Commission on British Muslims and Islamophobia (1997); Haut Conseil à I'Intégration (2000); Jacobson (1997); Joly (1995); Joly and Nielsen (1985); Kahani-Hopkins and Hopkins (2002); Kepel (1993); Khosrokhavar (1997); Leveau (2002); Lewis (1994); Modood (1994 and 2000); Brahm Levey and Modood (2010); Nielsen (1999); Pinto (2004); Roy (2005); Werbner (2002). 
tion in education, the labour market and Islamic religious and cultural life, with in France a special emphasis on issues revolving around dress code. ${ }^{8}$

Turning to participation in political life, the specific question of Muslim women's participation in politics has to be related to the relationship between politics and women in general. It is widely assumed that women are less interested than men in politics, as recounted by Duverger $\left(1955^{\circ}\right)$. A large debate has taken place on these issues, mostly among feminist scholars. Indicators sought to account for women's participation reveal that involvement in politics is commensurate with educational levels and degrees of employment outside home (Allwood and Wadia, 2000: 141). Assumptions about the disinterest of women in politics have been challenged on several grounds. It has been argued that this situation is changing with women's circumstances being altered (socialisation, education, employment) and with women also acquiring a clearer stake in politics as the welfare state is taking over some of their traditional functions (Christy, 1994: 27). Another major criticism is methodological as both terminology and definition are said to warp surveys on women's participation. The term "political" is posited as "off-putting" while formulations of a similar content under "important social issues" prompt much greater interest (Allwood and Wadia, 2000: 139). In addition, it has been put forward that the classical definition of politics, i.e. political parties and electoral politics, has excluded other forms of participation which are precisely the ones in which women tend to take part:

"Women do not participate less than men; instead, they participate differently [...] more ad hoc and unstructured community associations, voluntary organizations and protests groups." (Githens et al., 1994: 25-26)

A politics of ethics was also developed by women in extreme conditions of repression (Waylen, 1998: 161). Altogether, writings on the participation of women in politics demonstrate an active interest on their part albeit under diverse modes. ${ }^{10}$ It is important to take these findings into account in order to make a space for the wide variety of actors and types of action in politics which also include women. This is why, in lieu of a traditional acceptation of "politics", this research opts for an expanded definition of politics and participation in politics ${ }^{11}$ which includes what is termed "civic engagement", such as involvement in associations and the voluntary sector (Adler and Goggin, 2005; Zukin et al., 2005; Joly and Wadia, 2017).

The actual participation of women from Muslim communities in the public space, in the shape of civic and political engagement counts a limited amount

8 Such as Afshar et al. (2005); Ahmad (2001); Amiraux (2003); Bhimji (2012); Gaspard and Khosrokhavar (1995); Guenif-Souilamas (2000); Haddad (2005); Haw (1998); Jawad and Benn (2003); Knott and Khokher (1993); Kocturk (1992); Macey (1999); McAndrew (2006); Roald (2001).

9 Quoted in Allwood and Wadia (2000).

10 Such as Allwood and Wadia (2000); Charles and Hintjens (1998); Enloe (2004); Garcia (1994); Githens et al. (1994); Johnston (1994); Randall (1994); Yuval-Davis (1998).

11 Chowdhury and Nelson (1994: 18); Zukin et al. (2006: 7); Norris (1991); Wadia (2015). 
of writings ${ }^{12}$ which fall short of investigating the field in sufficient depth. This is where our research finds it full place. The ESRC project investigated the political and civic participation of Muslim women in their interaction with three central reference groups, the family/community, the Muslim group and wider society and documented the deployment of their capacity of action. However, this paper has a more limited remit and focusses on their interaction with wider society in order to ascertain the obstacles and enablements which the women themselves identify in terms of their opportunities to participate in civic and political life. This article also makes a point of developing an analysis deriving from the women themselves. The main objective of this article is thus to give Muslim women a voice and expound their viewpoint on an area of participation which has not been much explored. Thus, there is no separate section dedicated to findings on the women's stance but those are integrated into the main body of the article. This is the central thread leading our presentation of the societal framework surrounding their participation, a framework which was characterised by the prevalent biological racism of post-World War II France and Britain to be subsequently complemented and outstripped by the emergence of Islam and anti-Muslim prejudice from the 1990s onwards. Finally, the article attests the women's capacity of analysis and aspirations to engage into the public sphere.

\section{Early post World War II and Biological Racism}

Populations of Muslim background who settled in Britain and France in the aftermath of World War II (WWII) mostly find their origins in former colonies, respectively from the Indian Subcontinent (Pakistan, Bangladesh, and East Africa) and the North African region (Algeria, Tunisia, Morocco). Those groups thus inherited the racist attributes and stereotypes mooted through the era of colonialism and its ideological arm (Memmi, 1972). They remain today the majority Muslim contingent in Britain and France, despite subsequent arrivals from other Muslim majority countries such as Afghanistan, Bosnia, Iran, Iraq, sub-Saharan African countries and Turkey. During the first decades of their installation, racism and racial discrimination were the most significant societal factors which generated the mobilisation of populations of Muslim background alongside other immigrant groups. The question of Islam remained mostly unheeded.

\section{Britain}

In Britain, the early period of immigration after WWII was marked by countless instances of discrimination in everyday life, in housing, education and employment. In public places such as restaurants and pubs "coloureds" were often refused entry and it was not unusual to spot in the windows of rooms for rent a sign making it clear that blacks and other kinds of "coloureds" were not welcome. This was accompanied with recurrent acts of verbal and physical violence which culminated into the Notting Hill (London) and Nottingham racist riots in 1958 (Rex, 1988). Racial markers dominated the scene while Islam was

12 Such as Bano (2012); Boutedlja (2011); Brittain (2013); Burlet and Reid (1998); Cheruvalli-Contractor (2012); Christy (2002); Gaspard and Khosrokhavar (1995); Joly and Wadia (2017); Khiabany and Williamson (2008); Killian (2003); Maumoon (1999); Maynard (1994); Ray (2003); Ryan (2011); Werbner (1996); Williamson and Khiabany (2010). 
not noticeable among stereotypes and prejudices. Women interviewed who lived through that period enumerated the insults and obstacles they faced. At school, they were automatically geared to substandard secondary modern schools which prepared them for menial manual jobs; one woman who against all odds subsequently obtained a PhD and pursued an academic career, explained how the highest ambition proposed to her by the school career counsellor was to opt for nursing (Birmingham). Non-whites had great difficulty finding accommodation; Jameela (Birmingham) described how her family resorted to enlisting the name of an English friend to overcome otherwise insuperable barriers to purchasing a property. In employment, the women were victims of open discrimination such as Ahlam (Birmingham) who was bypassed by a less qualified white colleague when she applied for promotion. While recognising that such blatant racial discrimination has decreased, Sultana still quoted "colour" as a weightier basis of disadvantage than levels of education or income (Birmingham).

However, an accident of history meant that those immigrants from the New Commonwealth ${ }^{13}$ held an important resource initially designed for white Dominions but which was subsequently extended to non-white decolonised nations joining the Commonwealth: Commonwealth nationals were British citizens with all associated political rights and all formal social rights when they settled in the UK (Joly, 2001). Moreover, all foreigners were allowed to form associations, an important potential advantage for their settlement (Rex and Tomlinson, 1979). Nonetheless, New Commonwealth immigrants often fell short of actually accessing the social rights to which they were entitled (Rex, 1988). As a consequence, from the early 1960s, discrimination generated massive mobilisation on their part which comprised campaigns, pickets, lobbying, pressure groups in the shape of associations, demonstrations and active participation in political parties and electoral politics, a mobilisation which operated a pivotal influence in the development of anti-discrimination policies (Joly, 2012). A few of the older women interviewed in Birmingham who had joined those movements testified to their magnitude. This culminated into the 1976 Race Relations Act (RRA 1976) which remains the strongest piece of legislation against discrimination in Europe and was a model for Article 13 of the Maastricht Treaty and the 2000 European Council directive against discrimination. The subsequent British multicultural policy which responded to the 1980s riots in most large industrial towns, incorporated the recognition of ethnic communities and their cultural specificities. This model attracted controversies and was in the $21^{\text {st }}$ century heavily decried from diverse sources, in particular by the British government. Some of the women interviewed also deplored what they identified as a collusion between government and traditional elder males, evidenced by the government's official recognition of the latter which strengthened the upper hand they exercised on their ethnic and religious groups. Notwithstanding, several of our informants stressed the significance of rights won throughout that early period which not only forced through the official acceptance of different populations within British society but also established for them a culture of participation and activism in the public arena. In addition, the incorporation of cultural claims in the multicultural model facilitated the recognition of religious claims in the offing.

13The term of New Commonwealth is used to cover former British colonies which joined the Commonwealth when they gained their independence after World War II and whose population is not white (unlike that of Australia, New Zealand and Canada). 


\section{France}

In France, two historical and structural factors militated against similar gains in the corresponding period. In the first place, most immigrants from former colonies held the status of foreigners so that they did not, as in Britain, enjoy political or social rights of any kind and were not even allowed to found associations until 1981. Secondly and more importantly, the racism inherited from the colonial period was further fed and stoked by the Algerian war of independence and concomitant French war propaganda (Joly, 1991). Racism primarily targeted people of Arab background so that discrimination in all domains affected them, with young men falling victims of sometimes lethal physical violence. The frequency and impunity of those crimes led the so-called "second generation" to organise a mass movement, la Marche pour l'égalité in 1983. Many young women at the time took part in this broad movement; among the women interviewed several related their activism in the Marche itself and its aftermath, engaging in local politics, participating in associations such as the Mouvement contre le racisme et pour l'amitié entre les peuples and SOS Racisme, etc. Older Muslim women interviewed remember that period as the awakening of their political awareness and the launching pad of their participation in the public sphere. However, success and gains remained mitigated and ephemeral because they were undermined by changes in the parliamentary majority and thus failed to establish challenges to discrimination and racism on solid bases. In addition, the emergence of the Front National in the 1980s turned the control of immigration into an electoral ticket which has continued to gain further strength until 2017.

In both Britain and France, this period witnessed large scale mobilisation among populations of immigrant origin including those of Muslim background. These movements were grounded on "race" and class bases in Britain and on "race" and citizenship bases in France. A number of Muslim women embraced this scope of participation in the public sphere, as attested by our interviews. The periods examined above saw the height of biological/phenotypical racism which subsequently shifted its emphasis onto Islam and Muslims. This does not imply that biological racism has vanished in the $21^{\text {st }}$ century in Britain or France. This is illustrated through incidents quoted by women in our research, such as Diana, a Muslim holder of a degree who was mistaken for a cleaner because in her words, "what can we do about it; black women are only able to do a cleaner's job". To which she adds "Blacks and Arabs do not have their place here. France does not do anything for them or for their neighbourhoods except for sending the police" (Paris).

\section{Muslims and Islam in Britain and France}

While in the first post WWII decades, racial and ethnic categorisations occupied public discourse, those were gradually eclipsed by the emergence of Islam from the 1990s onwards. A dual process took place which involved selfdefinition by Muslims qua Muslims and categorisation by majority society. It is worth differentiating self-definition and categorisation (Jenkins, 1997), the former inferring that populations of Muslim background put forward claims related to the practice of their religion from within the group whereas the latter derives from an ascription from without at the hands of the majority group. 
Unmistakably, in the 1990s, biological racism was superseded by a novel negative categorisation by majority society, pointing to Islam and Muslims.

In Britain, Muslim populations had embraced the same modalities and strategies of action as immigrants had done previously in the shape of ethnic minorities. They mobilised initially on the local level, to subsequently expand their action nationally in the end of the 1980s, with large-scale protests against the publication of Salman Rushdie's Satanic verses and the Education Reform Act 1988. Muslims won multiple modes of accommodation taking them into account in the public sphere such as planning permission for mosques, modifications in the school curriculum, and adjustments in hospitals, in prisons and generally in the public domain. Populations of Muslim background thus made a place for Muslims in British society, in institutions and in the public space (Joly, 1995; Nielsen, 1992). One case in point is highly pertinent to Muslim women: the wearing of the hijab (headscarf) became completely normalised so that it is now worn in the political arena, in schools, in hospitals, in prisons and in the police without any questioning, a situation stressed by the women we interviewed. In France, there had been harbingers of claims by some Muslims for the recognition of religious rights to facilitate practice such as planning permission for mosques, but those demands remained modest and failed to score noticeable success. At the end of the 1980s, the headlines were hit by a Creil school where some parents had sent their daughters with a headscarf; the law suits which ensued resulted into a decision by the Conseil d'État that they should be allowed to wear their hijab at school as long as they did not proselytise (Joly, 2007).

In $21^{\text {st }}$ century Britain and France, Islamophobia ${ }^{14}$ has risen to prime time with its cortege of prejudices and hostilities. For women, this is compounded with aggravated stereotypes attached to Muslim women who are perceived as passive, submissive, homebound, confined to the role of mothers and wives. Countless examples were cited by the women interviewed. Reema, a senior social worker in Britain related how, when she left the hospital after giving birth, a friendly nurse greeted her goodbye with a "see you next year, dear"', grounded on the presumption that she was programmed to produce a child a year (Birmingham). Lina, a graduate who wore a headscarf was addressed by her doctor as though she was "illiterate and a simpleton" (Nanterre). In general, the fact of being a Muslim woman sufficed to incite negative connotations but the wearing of a headscarf added a new layer of prejudice as it was commonly assumed to constitute a proof that she conformed to the usual stereotypes associated with the image of a Muslim woman. Nationally, majority society's relationship to Muslims and the rise of Islamophobia which surrounded the experience of Muslim women in the two countries, followed differentiated courses in Britain and France.

\section{Britain}

First of all it is worth noting that most of the Muslim women we interviewed stressed their "Britishness" over and above any other national identification. Abida, a sixth form college student summarised a widespread viewpoint among

14 We use this term according to the meaning provided by Commission on British Muslims and Islamophobia (2004). 
Muslim women, namely that being British and Muslim were not exclusive of each other, a feature which they celebrated.

"You can keep your identity and still be part of this society and that's the great thing about British society, I don't think you need to give up any of your religion." (Birmingham)

As a conclusion, the women stated that they squarely espoused participating in British society and advocated against enclosure in one's ethnic or religious group. The women noted that British society opened doors which otherwise might remain closed. Access to education and taking up employment in particular were perceived as a chance to seize additional life and participation opportunities such as "extra training, getting involved with unions" (Tahani, Birmingham). The women quoted support they had gained from varied quarters in British society. Leesha, from a modest family of rural Bangladeshi background and whose father was illiterate was able to study Performing Arts at university and away from her home town because her drama teacher came to speak to her parents and convinced them to agree. She joined a performing troop, found employment in a secondary school and engaged in a good number of activities in the public space. Although their presence in conventional political spheres remained more limited, some of the women interviewed had been encouraged to pursue a political career within the ranks of Respect and the Labour Party and to an extent among the other political parties: a few of them had stood as candidates for the Parliamentary elections and a number had won municipal councillors' position.

Although anti-Muslim prejudice is evidenced from the 1990s in Britain, two events had an enormous impact on the experience and engagement of Muslim women: the 11 September 2001 events in 2001 (9/11) and the 7 July 2005 suicide bombings in London (7/7). In 2001, Tony Blair and his government fully identified with Bush's "War on Terror" and intervened militarily both in Afghanistan and Iraq. Externally, this signified a momentous offensive against Muslims on an international scale. This was coupled internally by anti-terrorist legislation, policies and propaganda with their repressive paraphernalia. It started in the aftermath of $9 / 11$ and was greatly reinforced in 2005 . At the same time, Tony Blair made declarations designed to placate the Muslim electorate which was a traditional Labour stronghold (Press conference, 05/08/2005). While racial discrimination has been the object of powerful legislation and policies, Muslims are not so well protected against religiously based discrimination and racism because the religious criterion is not included in the 1976 Race Relations Act and its 2000 Amendment. Furthermore, the 2010 Equality Act which includes a religious criterion is a weaker piece of legislation. For all instance and purposes, the former racism against blacks that was prevalent and pervasive in the 1970s has been transferred onto Muslims. One interlocutor from the Birmingham Race Action Partnership in our SI group summarised it as follows "Faith is the new Black", a reference to an earlier period when young Blacks were perceived as the main threat and the epitome of "mugging", dangerous delinquency and threats of violence (Birmingham). A moral panic prevails today similar to the one denounced by Stuart Hall in the 1970s (Hall et al., 1978), Blacks being replaced by Muslims (whatever their "colour"). The rise of Islamophobia has been evidenced by opinion poll data on attitudes towards Muslims between 2008 and 2010 (Heath and Martin, 2013: 1006). Anti-terrorist measures were accumulated 
through five pieces of anti-terrorist legislation in eight years between 2000 and 2008 (Kapoor, 2013: 1030). Raids in Muslim neighbourhoods and arrests of young people multiplied especially after $7 / 7$ as testified by the Ministry of Justice report which took note of the increase in searches under the Terrorism Act 2001: 37,000 in 2006-2007, 117,000 in 2007-2008, and 148,000 in 2009 (Ibid:: 1041). If deemed an inexorable threat, individuals can be extradited and their citizenship removed (Ibid.). The English Defence League (EDL) rose with fresh vigour, demonstrating against the "threat of terrorism" but also alleging that Islam embodied a peril for English culture.

Immediately after 9/11, menacing rumours ran rife and a sentiment of fear prevailed among British Muslim communities in awe of what could hit them. Physical and verbal attacks multiplied against Muslims or those who were mistaken for Muslims such as other South Asians. Someone insulted and spat at Sabreena who was walking along in the centre of Birmingham with her child (Birmingham). Several women interviewed were put on the spot to account for the 9/11 Twin Towers events, either very aggressively as though they were collectively guilty or because, being Muslims, they were assumed to be "chief witnesses".They also signalled that the religion which they had sometimes taken for granted suddenly assumed a new significance for them (Sadiqa, Coventry). For Muslim women, these events also unexpectedly opened a window of opportunity and induced an upsurge of their political participation. This is one most remarkable consequence of Britain's war against terror with regards to Muslim women, in so far as it set them on a long-term course of engagement exponentially continuing to expand. Most avenues of political participation had been so far occupied by traditional male community leaders but they had kept a low profile on the question of the war, for fear of being penalised if they raised their voice in opposition to the government. The women took advantage of this window of opportunity and seized upon this opening, being motivated by a heightened sense of outrage at what they considered an unjust war. A good number of the women we interviewed had joined Stop the War Coalition (Stop the War), which had been launched by the left opposition to the Labour government (Joly, 2007), and/or taken part in demonstrations against the war. Several Muslim women became secretaries of regional or local branches; one of our informants rose to be the Chair of Stop the War and embarked on a striking political career.

Somehow, the 7/7 events provoked a further expansion of Muslim women's activism. The government, which was seeking additional interlocutors from Muslim communities with the purpose of combatting terrorism, homed on young Muslims and women hitherto unnoticed since male elder leaders had dominated the representation of communities. This move by the government was based on the estimation that young people needed to be co-opted or neutralised and on the assumption that women were more "peaceful" and could thus be mustered as a useful buffer against terrorism. They were invited to Downing Street and the government programme against terrorism, the Violent Extremism PathFinder Fund (Prevent), contributed to funding a greater number of Muslim women's associations through the municipalities. Prevent funding was used by and boosted several women's associations, most of whom succeeded in maintaining their independence from state influence although the Prevent programme remained highly controversial and was indicted for turning Muslims 
into suspect communities (Joly and Wadia, 2012). A number of our informants had created or participated in associations, engaging with a wide variety of social, political, cultural and religious issues. Suffice to cite a few of those associations as follows: Muslim Women's Network UK broached all matters or questions affecting Muslim women (Birmingham); Ulfah Arts proposed cultural performances involving and addressing Muslim women (Birmingham); Apna Haq helped women victims of domestic violence (Rotherham); and a selection of charities such as the Muslim Red Cross and the Samaritans also attracted the participation of Muslim women. Others dealt with themes related to Islam in British society (Joly and Wadia, 2017).

In Britain, the paradox was that on the one hand, the "War against terror" abroad and at home had turned Muslims into a target of exacerbated prejudice and hostility, generating widespread Islamophobia. On the other hand, it had produced a more inclusive outcome for Muslim women. Those were fully integrated into the mass movement against the war with or without headscarves. All including headscarved Muslims felt confident that they could join in because the headscarf had become fully normalised and because many on the left had defended and continued to uphold Muslims' rights as an integral part of the general fight against discrimination and prejudice. Muslim women became fullyfledged actors in the public arena.

\section{France}

In France, the 9/11 events of 2001 formed less of a watershed than in Britain in terms of their civic engagement. Some of the women interviewed encountered hostility in the following days and it is true that the threat of "terrorism" purveyed good opportunities for the state to tighten the security agenda, while it fed support to extreme-right and right-wing political leanings. Notwithstanding, France did not intervene in Iraq and the French polity and society did not identify with the US "War on Terror", so that the international dimension that nourished Islamophobia was less prominent than in the UK. In France, the question of Islam became more of a national affair. Since 2002, right-wing politicians were set on a course to seduce voters away from the Front National, largely on an anti-Muslim ticket and many left-wing politicians failed to challenge this agenda. Hence, Islamophobia has risen in France to untold heights. Suffice it to quote the November 2013 Cevipof Ipsos opinion poll (Le Monde, 21/01/2014) which documents that $74 \%$ of French people think that Islam is an intolerant religion and that Islam and France are incompatible. This is endorsed by Hamida who felt that Islam was perceived in France as "a barbarian, archaic religion that should go back to its countries." (Mantes la Jolie). The relationship to Islam was erected as a national issue so that competing political entities seized upon it to build up their popularity reclaiming the exception française (Dominique Vidal, Le Monde Diplomatique, February 2004), namely laïcité, ${ }^{15}$ which has had a disproportionate impact on Muslim women. As a testimony that Islam has become an intrinsically national issue, it is worth mentioning that laïcité has been converted into a central tool used as a rallying cry. Baubérot (2004: 6) noted that since the 1990s, laïcité has been constructed as an identity marker. Some scholars have called it France's fourth religion (Pinto, 2004: 78). The Stasi Commission appointed

15 Beckford et al. (2005: 79-80). 
by President Chirac published the Rapport de la Commission de réflexion sur I'application du principe de laïcité dans la République on 11 December 2003, which resulted into the law of 15 March 2004 prohibiting the wearing of ostentatoire religious signs at school. The Stasi report did not hesitate in stating that "France has erected laïcité to the rank of a founding value" (Stasi, 2003: 3).

For a number of women of Muslim background the way laïcité has been pursued politically has turned them into hostages of an ideological tug of war. The legislative parallel to the "War on terror" in the UK has been the onslaught against Muslim women's dress code in France. Women of Muslim background have thus been placed centre stage in an offensive against Muslims. The 2004 law prohibiting ostentatoire religious signs at school in reality specifically targeted the Muslim headscarf. The 2010 Law forbidding face concealment in public spaces (which includes the streets) was couched in general terms but it is unmistakably evident to all that it was directed at the full face veil. A novel kind of discrimination enshrined in the law is thus exercised by the French state which is creating an insidious structural and cultural framework hostile to Islam and Muslims and, in particular, to Muslim women. This has generated a feeling among several of the women interviewed that they were not permitted to combine being at the same time French and Muslim, a dual identity which they wished to claim for themselves. These legislative and societal moves have had a significant impact on Muslim women's capacity of action. They have caused a strong polarisation of positions and an almost obligatory cleavage either in support of or in opposition to laïcité. In terms of possibility of participating in the spheres of majority society a dichotomy was installed. The full range of potential participatory opportunities is open formerly (if not always in practice) to women who do not choose to wear distinctive signs of their faith. Conversely, a good number of participatory avenues are closed to those who deem it important for their practice to wear a headscarf.

The question of laïcité and related issues elicited varied opinions among the women interviewed. We did not uncover a simple correlation of Muslim believers or practising Muslims who pronounced themselves against laïcité while atheists and/or agnostics would agree with it. The heterogeneity of opinions was a great deal more complex. On one hand, some women of Muslim background voiced their support of laïcité. Some of our informants who saw in Islamic prescriptions an impediment to gender equality and to their full participation in the public spheres stated that laïcité provided protection to women of Muslim background. Hayat, thirty, an atheist whose family had suffered from Islamist threats in Algeria valued laïcité. In the opinion of Safa, forty-four (Paris), an activist for women's rights who was not a practising Muslim, laïcité constituted a protection for women against fundamentalism. Najima, a barrister and a councilor of Tunisian background, a follower of a spiritual branch of Islam advocated for the separation of private and public spheres and agreed with laïcité (Saint-Fons). Others considered that laïcité enabled them to practice their religion as they wished without interference from Muslims and non-Muslims alike (Emani, SaintDenis). Several of our informants valued the Republic which awarded them the tools of autonomy through educational grants and opportunities to be active in wider society's arenas. A number of women of Muslim background who were atheist, agnostic or who practised a private form of Islam have indeed had access to participation in French institutions, in political arenas or in the public 
domain generally. A few hold positions in municipal councils or in the Sénat, others for instance are active in parents' associations and trade-unions. Our research demonstrates aspirations to an active participation in all instances of the public domain on the part of those women.

On the other hand, the 2004 Law banning the headscarf at school has fostered widespread mobilisation among Muslim women such as the organisation of the campaign Collectif une école pour tou-te's, which many of our informants supported on an anti-discrimination platform and in the name of freedom of choice, independently of their adherence to a faith. Indeed, this campaign gathered believers together with non-believers as many wished to protest against the barring of headscarf-wearing women from participating in institutions. For instance, in some schools, mothers who wore a headscarf were not allowed to accompany their children to help with school outings on account of the 2012 Luc Chatel Circulaire, which resulted into a good deal of arbitrary negative decisions on the part of school heads. This generated some mothers' mobilisation who won a court case (Kassir and Reitz, 2016). On the whole, broad structural impediments are in place which hamper the participation of headscarf-wearing women in the public space and in institutions, in the political arena, in under eighteen education and in a whole range of employment sectors. Regarding the latter, in effect, it means that at least $30 \%$ of the active population is affected since this is what corresponds to civil service and public service employment. An emergent trend of policies and practices ban them from a whole spectrum of sites of participation and many of the women interviewed quoted their exclusion from a number of activities (Joly and Wadia, 2017).

Moreover, there are sombre sides to the after effect of those laws, discourses and policies crystallising around female dress code. One of them is a kind of ideological permeation of French culture and opinion against vestimentary symbols of Islam; the menace of a legal prohibition being extended to larger sectors animates a presumption that it has already happened, as in universities, associations or private business (while this is not the case). A few examples cited in our interviews can illustrate this tendency in environments where the Muslim headscarf is entirely permitted by law. A dinner lady refused to serve a Muslim woman wearing a headscarf in the CROUS canteen (university restaurant) (Asala, Mantes la Jolie). A university lecturer told one of his students that if she kept her headdress on, either she would walk out or he would (Asala, Mantes la Jolie). One of the women reported that she was denied participation as a volunteer to the Restos du Coeur, a charity, because of her headscarf. A similar occurrence in the Restos du Coeur of Le Mans was documented in the media (Le Monde, 11/11/2013). The private employment sector seems to be pervaded by this dominant view antagonistic to the headscarf. On 11 February 2014, a large private company, Paprec announced its adoption of a Charte de la laïcité prohibiting inter alia the headscarf among its 4,000 employees; in clear contravention of the 2000 European Directive on discrimination in employment which comprises the religious criterion. Several of the women interviewed have denounced an increased heightening of bids aiming to control their dress code which is accompanied with enhanced hostility. They add that this type of discrimination is not limited to religious criteria but is aggravated by a gender based discrimination since Muslim males get off Scott free. Indeed, the fears of our informants have been further confirmed by the spreading of dress code 
led stigmatization, either on the part of institutional actors, such as the thirty municipalities that banned the "burkini" on the beaches of Southern France in August 2016, in the name of "good mores, laïcité and public order"16 or at the hand of individuals like a restaurant owner in Saint-Denis (Tremblay-en-France) who barred entry to two women wearing a headscarf (Le Monde, 30/08/2016).

A further insidious side-effect on Muslim women's capacity of action is a potential internalisation of the headscarf prohibition. Some dared not venture into sectors where they expected hostility on account of their headscarf. Several of the women interviewed also pointed out that these measures claiming to protect women in fact added insult to injury and enacted a self-fulfilling prophecy. While the justification for prohibiting the headscarf has been advanced that it protected Muslim women and secured their autonomy, it performed quite the opposite in the opinion of several women interviewed, because it confined them away from many mainstream areas and signalled them as a ready target of gender based discrimination as a result of their visibility (Kadija, Livry-Gargan).

This does not mean that Muslim women altogether have given up and renounced participation in civic and political action. On the contrary, as in Britain many were highly motivated to intervene, particularly on issues of social justice and on ethical issues. They developed alternative strategies and paths of action to be able to do so. For instance, rather than engage with mainstream politics and institutions, Muslim women who adhered to a religious dress code joined and/or created associations to pursue their goal; associations to support education, to promote female sport activities, to defend women against domestic violence, etc.

\section{Capacity of Analysis and Engagement}

The participation of women from Muslim communities in British and French society is staged through complex interconnections which involve their own community, international Islam and wider society. Many of the women interviewed displayed their political awareness through a sharp capacity of analysis about their social and political environment concerning the national and international conjunctures which affected them. As a consequence, in both Britain and France the women expressed their concern. They squarely laid at the foot of western society the responsibility of what they called "extremist" features of Islam which they all opposed; such as the spread of the niqab/burqa, the denunciation of democracy concomitant with calls for an Islamic state, a certain literal application of the sacred texts (denounced by almost all the religious women we encountered), the separation of men and women and most of all, terrorist action and suicide bombings; all developments which they felt augmented the obstacles to their autonomy and their participation in the public sphere. The central explanations put forward by the women for the salience of such forms of Islam in western society underlined exclusion and racial/religious discrimination, combined with the stigmatisation of their religion. This was the opinion of

16 Despite the Conseil d'État's decision to invalidate the 5th August decree of VilleneuveLoubet which acts as jurisprudence, the debate is still open as stated by Prime Minister Manuel Valls, as well as by Nicolas Sarkozy who promised a law to ban the headscarf and all religious signs in the public space (Le Monde, 29/08/2016). 
most religious as well as non-religious women we interviewed. In the women's view, it was clear that $9 / 11$ did not only bring Islam to the forefront internationally but also triggered a backlash vis-à-vis Muslims in western societies, so that the sense of threat which Muslim shared encouraged them to come together as a closer group and re-claim their religion with a stricter interpretation.

"I think it is because politically we are so intimidated and [...] they're coming down on Muslims everywhere. Muslims are sort of sticking together and going back to that notion of Islam and then thinking that this is the right notion." (Birmingham, Ahlam)

According to Wahida, Muslims' urge to reaffirm their faith was largely prompted by the scornful indictment of Islam on the part of majority society, readily equating Islam with terrorism (Fontenay sous Bois). In the main, the women largely imputed extreme forms of re-Islamisation to the societal context and blamed its array of exclusion, poverty, and stigmatisation. Souhila concluded that social disenchantment had led to Islamic radicalisation and that the appearance of the niqab was linked to aggressive foreign policy against Muslim countries (London). In France, the "most extreme [Islamist] practices" were attributed to the rejection of Muslims by society (Fatouma, Paris). On the whole, this trend mostly concerned young men but it was noted that these explanations were sometimes put forward for young women. The women had a particularly sharp insight into the tenets of current tensions concerning people of Muslim background. Salima provided an analysis of reasons behind the wearing of the hijab, blaming policies which have generated ghettoes and sites of "nonlife" (Paris). Nour concluded that wearing the hijab was often a political decision to assert that Muslims would not yield to intimidation (Birmingham). In France several women raised the issue of laïcité whose rigidity they detected had been mirrored by an increasingly rigid interpretation of Islam (Keltoum, Paris); in her view, "laïcs" extremists largely fed Islamic extremism (Paris).

These developments are not anodyne with regards to obstacles intervening in the capacity of Muslim women to participate in the public sphere. An additional collateral damage of Islamophobia thus specifically impacted women. The women explained how widespread anti-Muslim prejudices had generated re-islamisation of a certain kind, commanding tight prescriptions in the running of their life which the vast majority of the women interviewed rejected. In practice, they detected in the latter a re-invention of Islam interpreted by men for men with the complementary purpose of controlling women as, in Mounira's words, "male supremacy under the guise of religion" (Paris). The organisations promoting such interpretation were proving particularly attractive to young men. The women argued that the political offensive against Islam had caused group enclosure for protection and a need for solidarity which jeopardised their aspiration to greater autonomy within the community group and the family. It had led to the tightening up of in-group constraints, either through the recoiling into traditional Islam, or through the growth of Islamic trends reasserting the need to return to a reading of the texts restricting women furthermore. This had produced a dual reaction on the women's part. On one hand, it had spurred a good number of religious women to re-claim Islam in their own manner, seeking arguments therein in support of greater autonomy against ethnic traditions and against political Islamist trends: they created and belonged to separate female Muslim study groups to assert their rights. On the other hand, attacks on Islam 
and its worth were perceived as tantamount to an offense on the personal integrity and dignity of Muslims. As a result, many Muslim women felt that their endeavours to defend their autonomy as women had to yield precedence to their loyalty towards a group already besieged with negativity. Naja took note that the belittling of Islam inevitably entailed greater control on women from within the communities and enhanced the difficulties they faced in gaining their autonomy (Paris). For instance, Keltoum stated that despite her disapproval of the full veil, she could not challenge it because such a move would add onto the stigmatisation of Islam which she condemned (Paris). This was a common reaction on the part of Muslim women for whom majority society's relationship to Islam generated obstacles in the fight for their autonomy within the group and hampered their ability to engage in the public sphere.

Throughout our empirical research it was shown that the women's noticeable interest in civic and political initiatives was underpinned by a strong sensitivity to all manner of injustice, among the ethnic group and in wider society on the national and international scenes. This was based upon their own experience of disadvantage on gender, social, racial ethnic and religious criteria, either personally or indirectly. Their links with countries outside Britain and France also meant that they kept well-informed on international events particularly as those affected the developing world including Muslim regions. The women denounced the poverty engineered by imperialist domination and corrupt politicians in those countries; they were concerned with issues of deprivation as much as situations of repression. While they were outraged by the international offensive against Muslims in connection with geopolitical and economic interests, they also condemned extremist Islam and advocates of terrorism.

The women's discourse on their social and political environment was translated into different modes of engagement with the aim of acting upon varied issues they deemed important. Our research evidenced the diversity of arenas wherein Muslim women exercised their participation. The majority of the Muslim women in our sample were committed to voting in national and parliamentary elections (Joly and Wadia, 2017). A few of them were active in electoral politics and traditional sites of politics such as belonging to political parties, standing and being elected to positions of municipal councillors, MPs, members of the higher chamber (the French Sénat and the British House of Lords). Other women engaged with mainstream institutions in education, health and trade unions. Many took part in demonstrations and campaigns, for instance against racism, against the banning of the hijab at school (in France), against the war in Iraq (in Britain), against the events in Gaza and Israel's military intervention (in France and Britain). However, what this research brings to light is the woman's predilection for action through associations and NGOs (Joly and Wadia, 2017). This included a multifarious panoply, such as transversal mainstream associations which included women of all backgrounds, specific ethnic associations or Muslim associations, ${ }^{17}$ associations oriented towards homeland issues or political/humanitarian issues, and a great deal of associations promoting

17 However, when the women engaged with associations which involved an ethnic or Muslim character, the latter were generally those that were created by and for women, independently of traditional associations. 
Muslim women's rights and well-being. Despite the obstacles they encountered, the women found ways of developing their participation in the public sphere.

\section{Conclusion}

In both Britain and France racism and discrimination followed a similar paradigm shift, concentrating on biological criteria in the initial decades of immigrants' settlement to subsequently focus on cultural and religious dimensions from the 1990s onwards. Arabs in France and Pakistanis/Bangladeshis in Britain were turned into Muslims in public discourse and policies. What stayed constant was the naturalisation and essentialisation of the characteristics selected for negative ascription. The same populations suffered a double jeopardy through a continuous process, being first targeted for their racial/ethnic characteristics and then for their religious markers. The latter occurred in a more inauspicious epoch fraught with neo-liberalism, economic crisis and the decline of general solidarity. These successive frameworks of domination and discrimination have affected Muslim men and women alike. However, while Muslim women suffer from multiple disadvantages, on general racial and religious grounds, they additionally endure specific prejudices as women of Muslim background. In our article, the women themselves have identified and analysed the varied facets of this situation. Muslim women are well aware that they have to negotiate the manifold pitfalls assembled in their path so that they are able develop their participation and engage in the public sphere. Our research evidences their lucidity in the analysis of their circumstances and their high motivation to take part in the polis. Much of the women's engagement was generated by their ethical sense, which they emphasised. The women were motivated to take part in civic and political action through their strong ethical sense, holding up values above norms, solidarity against individualistic interests, and humanitarianism in the face of material greed. This constituted for them a catalyser of action and a powerful instigator of emancipation. 


\section{References}

Adler Richard P. and Goggin Judy J. (2005) What Do We Mean By "Civic Engagement"?, Journal of Transformative Education, 3 (3), pp. 236-253.

Afshar Haleh (1998) Strategies of resistance among the Muslim minority in West Yorkshire: Impact on women, in Nickie Charles and Helen Hintjens Eds., Gender, ethnicity and political ideologies, London, Routledge, pp. 107-126.

Afshar Haleh, Aitken Rob and Franks Myfanwy (2005) “Feminisms", Islamophobia and Identities, Political studies, 53 (2), pp. 262-283.

Ahmad Fauzia (2001) Modern traditions? British Muslim women and academic achievement, Gender and Education, 13 (2), pp. 137-152.

Allwood Gill and Wadia Khursheed (2000) Women and politics in France 19582000, London, Routledge, 270 p.

Amiraux Valérie (2003) Discours voilé sur les musulmanes en Europe : comment les musulmans sont-ils devenus des musulmanes ?, Social Compass, 50 (1), pp. 85-96.

Amiraux Valérie (2002) The situation of Muslims in France, in Monitoring the EU Accession Process: Minority Protection, vol. 2, Budapest, Open Society Institute, pp. 101-103.

Archer Margaret (2007) Making our way through the world, Cambridge, CUP, $343 \mathrm{p}$.

Archer Margaret (1995) Realist social theory: The morphogenetic approach, Cambridge, CUP, $353 \mathrm{p}$.

Bano Samia (2012) Muslim women in Shar'iah Councils; Transcending the Boundaries of Community and Law, Basingstoke, Palgrave MacMillan, 329 p.

Banton Michael (1967) Race relations, London, Tavistock, 434 p.

Baubérot Jean (2004) La laïcité en question, Paris, Institut Français de Relations Internationales, $16 \mathrm{p}$.

Baubérot Jean (2000) Histoire de la laïcité, Paris, PUF, 128 p.

Beckford James Arthur, Joly Danièle and Khosrokhavar Farhad (2005) Challenge and Change: Muslims in French and British prisons, Basingstoke, MacMillan Palgrave, $301 \mathrm{p}$.

Bertossi Christophe (2001) Les frontières de la citoyenneté en Europe : nationalité, résidence, appartenance, Paris, L'Harmattan, 300 p.

Bertossi Christophe and Duyvendak Jan Wilhelm (Eds.) (2012) National Models of Integration and the Crisis of Multiculturalism: A Critical Comparative Perspective, Patterns of Prejudice, 46 (5), pp. 417-426.

Bhimji Fazila (2012) British Asian Muslim Women, Multiple Spatialities and Cosmopolitanism, Basingstoke, Palgrave MacMillan, 147 p.

Boutedlja Naima (2011) Unveiling the truth: Why 32 Muslim Women Wear the Full-face Veil in France, New York/Budapest/London, Open Society Foundation, $77 \mathrm{p}$. 
Bowen John (2004) Pluralism and Normativity in French Islamic Reasoning, in Robert Hefner Ed., Remaking Muslim Politics, Princeton, PUP, pp. 326-346.

Bowen John, Bertossi Christophe, Duyvendak Jan Willem and Krook Mona Lena (Eds.) (2014) European states and their Muslim citizens, Cambridge, CUP, 302 p.

Boyer Alain (1998) L'islam de France, Paris, PUF, 369 p.

Brahm Levey Geoffrey and Modood Tariq (2010) Secularism, Religion and Multicultural Citizenship, Cambridge, CUP, 298 p.

Brittain Victoria (2013) Shadow Lives:The Forgotten Women of the War on Terror, London, Pluto Press, $182 \mathrm{p}$.

Burlet Stacey and Reid Helen (1998) A gendered uprising: Political representation and minority ethnic communities, Ethnic and Racial Studies, 21 (2), pp. 271-287.

Candappa Mano and Joly Danièle (1994) Local authorities ethnic minorities and "pluralist integration", Monographs in Ethnic Relations, 7, CRER, University of Warwick, $159 \mathrm{p}$.

Cesari Jocelyne (1998) Musulmans et Républicains. Les jeunes, I'Islam et la France, Bruxelles, Complexe, $156 \mathrm{p}$.

Charles Nickie and Hintjens Helen (Eds.) (1998) Gender, ethnicity and political ideologies, London, Routledge, $218 \mathrm{p}$.

Cheruvalli-Contractor Sariya (2012) Muslim Women in Britain: Demystifying the Muslimah, London, Routledge, 202 p.

Chowdhury Nadjma and Nelson Barbara (Eds.) (1994) Women and Politics Worldwide, New Haven/London, Yale University Press, 830 p.

Christy Maliha (2002) The International Women's Movement and the Politics of Participation for Muslim Women, The American Journal of Islamic Social Sciences, 19 (4), pp. 80-99.

Christy Maliha (1994)Trends in sex differences in political participation: a comparative perspective, in Marianne Githens, Pippa Norris and Joni Lovenduski Eds., Different roles, different voices: women and politics in the United States and Europe, New York, Harper Collins, pp. 27-37.

Commission on British Muslims and Islamophobia (1997) Islamophobia: A Challenge for Us All, London, Runnymede Trust, $92 \mathrm{p}$.

Daniel William (1968) Racial Discrimination in England, London, PEP, 251 p.

Dubet François (1999) Où en est la méthode de l'intervention sociologique ?, Paris, CADIŚ.

Dubet François (1994) Sociologie de l'expérience, Paris, Seuil, 271 p.

Dubet François (1987) La Galère : jeunes en survie, Paris, Fayard, 497 p.

Dubet François et Lapeyronnie Didier (1992) Les Quartiers de I'Exil, Paris, Seuil, $258 \mathrm{p}$.

Dubet François and Wieviorka Michel (1996) Touraine and the method of sociological intervention, in Jon Clark and Mario Diani Eds., Alain Touraine, London, Falmer, pp. 55-75. 
Enloe Cynthia (2004) The curious feminist, Berkeley, UCP, 367 p.

Garcia Alma (1994) The development of Chicana feminist discourse, 1970-1980, in Marianne Githens, Pippa Norris and Joni Lovenduski Eds., Different roles, different voices: Women and politics in the United States and Europe, New York, Harper Collins, pp. 190-195.

Gaspard Françoise et Khosrokhavar Farhad (1995) Le foulard et la République, Paris, La Découverte, 218 p.

Githens Maliha, Norris Pippa and Lovenduski Joni (Eds.) (1994), Different roles, different voices: Women and politics in the United States and Europe, New York, Harper Collins, 250 p.

Guenif-Souilamas Nacira (2000) Des "beurrettes" aux descendantes d'immigrants nord-africains, Paris, Grasset/Le Monde, 363 p.

Haddad Yvonne (2005) The Study of Women in Islam and the West: a Select Bibliography, Hawwa, 3 (1), pp. 111-157.

Hall Stuart, Critcher Chas, Jefferson Tony, Clarke John and Roberts Brian (1978) Policing the crisis; Mugging, the State and Law and Order, London, MacMillan, $425 \mathrm{p}$.

Haut Conseil à I'Intégration (2000) L'islam dans la République, Paris, La Documentation française, $204 \mathrm{p}$.

Haw Kaye (1998) Educating Muslim Girls: Shifting Discourses, Buckingham, OUP, $224 \mathrm{p}$.

Heath Anthony and Martin Jean (2013) Can religious affiliation explain "ethnic" inequalities in the labor market, Ethnic and Racial Studies, 36 (6), pp. 1005-1028.

Hirschman Albert (1970) Exit, voice and loyalty, Cambridge, Harvard University Press, $176 \mathrm{p}$.

Jacobson Jessica (1997) Religion and ethnicity: Dual and alternative sources of identity among young Pakistanis, Ethnic and Racial Studies, (20) 2, pp. 238-256.

Jawad Haifaa and Benn Tansin (2003) Muslim Women in the United Kingdom and Beyond: Experiences and Images, Leiden, Brill, 178 p.

Jenkins Richard (1997) Rethinking ethnicity, London, Sage, 224 p.

Johnston Conover Pamela (1994) Feminists and the gender gap, in Marianne Githens, Pippa Norris and Joni Lovenduski Eds., Different roles, different voices: Women and politics in the United States and Europe, New York, Harper Collins, pp. 51-60.

Joly Danièle (2016) Women from Muslim Communities: Autonomy and Capacity of Action, Sociology, 51 (4), pp. 816-832.

Joly Danièle (2012) “Race", ethnicity and religion: Emerging policies in Britain, Patterns of Prejudice, 46 (5), pp. 467-485.

Joly Danièle (2007) L'Émeute, Paris, Denoël, 327 p.

Joly Danièle (2001) Blacks and Britannity, Aldershot, Ashgate, 172 p.

Joly Danièle (1995) Britannia's Crescent: Making a place for Muslims in British Society, Aldershot, Avebury, $197 \mathrm{p}$. 
Joly Danièle (1991) The French Communist Party and the Algerian War, Oxford, MacMillan, $181 \mathrm{p}$.

Joly Danièle and Nielsen Jorgen (1985) Muslims in Britain: An annotated bibliography, 1960/1984, Bibliographies in Ethnic Relations, 6, Coventry, CRER, University of Warwick., $35 \mathrm{p}$.

Joly Danièle and Wadia Khursheed (2017a) Muslim women and power: Civic and political engagement in west European societies, Basingstoke, Palgrave MacMillan, $322 \mathrm{p}$.

Joly Danièle et Wadia Khursheed (2017b) La participation civique et politique des femmes de culture musulmane en Europe, Québec, Presses Universitaires de Laval, $328 \mathrm{p}$.

Joly Danièle and Wadia Khursheed (Coords.) (2012) Féministes et musulmanes, Hommes et Migrations, 1299, 158 p.

Kahani-Hopkins Vered and Hopkins Nick (2002) "Representing" British Muslims: The strategic dimension to identity construction, Ethnic and Racial Studies, 25 (2), pp. 288-309.

Kapoor Nisha (2013) The advancement of racial neoliberalism in Britain, Ethnic and Racial Studies, 36 (6), pp. 1028-1046.

Kassir Alexandra and Reitz Jeffrey (2016) Protesting headscarf ban: A path to becoming more French? A case study of "Mamans toutes égales" and "Sorties scolaires avec nous", Journal of Ethnic and Racial Studies, 39 (15), pp. 2683-2700.

Kepel Gilles (1993) À L'ouest d'Allah, Paris, Seuil, 348 p.

Khiabany Gholam and Williamson Milly (2008) Veiled bodies-naked racism: Culture, politics and race in the sun, Race and Class, 50 (2), pp. 69-88.

Khosrokhavar Farhad (1997) L'Islam des Jeunes, Paris, Flammarion, 323 p.

Killian Caitlin (2003) The Other Side of the Veil: North African Women in France Respond to the Headscarf Affair, Gender and Society, 17 (4), pp. 567-590.

Knott Kim and Khokher Sajda (1993) Religious and ethnic identity among young Muslim women in Bradford, New Community, 19 (4), pp. 593-610.

Kocturk Tahire (1992) A Matter of Honour: Experiences of Turkish Women Immigrants, London, Zed Books, $145 \mathrm{p}$.

Lapeyronnie Didier (1993) L'individu et les Minorités : La France et la GrandeBretagne face à leurs immigrés, Paris, PUF, 361 p.

Leveau Remy (2002) Islam in France, in Shireen Hunter Ed., Islam: Europe's second religion, London, Praefer, pp. 3-29.

Lewis Philip (1994) Muslim Britain, London, I.B. Tauris, 250 p.

Macey Marie (1999) Class, gender and religious influences on changing patterns of Pakistani Muslim male violence in Bradford, Ethnic and Racial Studies, 22 (5), pp. 845-866.

Maumoon Dunya (1999) Islamism and gender activism: Muslim women's quest for autonomy, Journal of Muslim Minority Affairs, 19 (2), pp. 269-283. 
Maynard Mary (1994) "Race", gender and the concept of "difference" in feminist thought, in Haleh Afshar and Mary Maynard Eds., The Dynamics of "race" and gender: Some feminist interventions, Abington, Taylor \& Francis, pp. 9-25.

McAndrew Marie (2006) The hijab controversies in Western public schools: Contrasting conceptions of ethnicity and ethnic relations, in Haideh Moghissi Ed., Muslim Diaspora: Gender, Culture, Identity, Abingdon/Oxford/New York, Routledge, pp. 51-166.

Memmi Albert (1972) Portrait du colonisé, Montréal, L'Étincelle, 146 p.

Miles Robert and Phizacklea Annie (1984) White man's country: Racism in British politics, London, Pluto Press, $184 \mathrm{p}$.

Modood Tariq (2000) Anti-Essentialism, Multiculturalism and the "Recognition" of Religious Groups, in Will Kymlicka and Wayne Norman Eds., Citizenship in Diverse Societies, Oxford: OUP, pp. 175-198.

Modood Tariq (1994) Muslim identity: Social reality or political project?, in John Rex and Tariq Modood Eds., Muslim identity real or imagined?, Birmingham, CSIC, 12.

Modood Tariq and Werbner Pnina (1997) The politics of multiculturalism in the new Europe: Racism, identity, and community, London, Zed Books, 276 p.

Nielsen Jorgen (1999) Towards a European Islam, Basingstoke, Macmillan, 156 p.

Nielsen Jorgen (1992) Islams, Muslims and British local and central government, Birmingham, CSIC Papers.

Norris Pippa (1991) Gender Differences in Political Participation in Britain: Traditional, Radical and Revisionist Models, Government and Opposition, 26 (1), pp. 56-74.

Parekh Bikhu (2000) Rethinking multiculturalism, cultural diversity and political theory, Basingstoke, Palgrave MacMillan, $400 \mathrm{p}$.

Patterson Sheila (1968) Immigrants in Industry, London, OUP Press for the Institute of Race Relations, $411 \mathrm{p}$.

Pinto Diana (2004) La France et les quatre religions, Esprit, pp. 78-88.

Randall Vicky (1994) Feminism and political analysis, in Marianne Githens, Pippa Norris and Joni Lovenduski Eds., Different roles, different voices: Women and politics in the United States and Europe, New York, Harper Collins, pp. 4-16.

Ray Kiely (2003) Constituting "Asian women": Political representation, identity politics and local discourse of participation, Ethnic and Racial Studies, 26 (5), pp. 854-878.

Rex John (1988) The ghetto and the underclass, Aldershot, Avebury, 140 p.

Rex John and Drury Beatrice (1994) Ethnic Mobilisation in a Multi-Cultural Europe, Aldershot, Avebury, $178 \mathrm{p}$.

Rex John, Joly Danièle and Wilpert Czarina (Eds.) (1987) Immigrant Associations in Europe, Aldershot, Gower Press, 247 p.

Rex John and Moore Robert (1967) Race, Community and Conflict: a study of Sparkbrook, Oxford, OUP, $320 \mathrm{p}$. 
Rex John and Tomlinson Sally (1979) Colonial immigrants in a British city: A class analysis, London, Routledge, $357 \mathrm{p}$.

Roald Anne Sofie (2001) Women in Islam: the Western Experience, London, Routledge, $339 \mathrm{p}$.

Roy Olivier (Éd.) (2005) La laïcité face à I'Islam, Paris, Stock, 172 p.

Ryan Louise (2011) Muslim women negotiating collective stigmatisation: “We're just normal people", Sociology, 45 (6), pp. 1045-1060.

Solomos John (1986) Riots, Urban Protest and Social Policy: The Interplay of Reform and Social Control, Research Paper, 44, CRER, University of Warwick.

Stasi Bernard (2003) Commission de réflexion sur l'application du principe de la laïcité dans la République, rapport au président de la République remis le 11 décembre 2003, 166 p.

Touraine Alain (2013) La fin des sociétés, Paris, Seuil, 656 p.

Touraine Alain (1978) La voix et le regard, Paris, Seuil, 315 p.

Touraine Alain (1973) Production de la société, Paris, Seuil, 543 p.

Wadia Khursheed (2015) Women from Muslim Communities in Britain: Political and Civic Activism in the 9/11 Era, in Timothy Peace Ed., Muslims and Political Participation in Britain, London, Routledge, pp. 85-102.

Waylen Georgina (1998) Women's activism, authoritarianism and democratization in Chile, in Nickie Charles and Helen Hintjens Eds., Gender, ethnicity and political ideologies, London, Routledge, pp. 146-167.

Werbner Pnina (2002) Imagined Diasporas among Manchester Muslims, Oxford, World Anthropology Series, 320 p.

Werbner Pnina (1996) Public spaces, Political Voices: Gender, Feminism and Aspects of British Muslim Participation in the Public Sphere, in W.A.R. Shahid and Pieter Sjoerd Van Koningsfeld Eds., Political Participation and Identities of Muslims in Non-Muslim States, Leiden, Kok Pharos, pp. 53-70.

Wieviorka Michel (2001) La Différence, Paris, Balland, 197 p.

Williamson Milly and Khiabany Gholan (2010) UK, the veil and the politics of racism, Race and Class, 52 (2), pp. 85-96.

Yuval-Davis Nira (1998) Beyond differences: Women, empowerment and coalition politics, in Nickie Charles and Helen Hintjens Eds., Gender, ethnicity and political ideologies, London, Routledge, pp. 168-189.

Zukin Cliff, Scott Keeter, Molly Andolina, Krista Jenkins and Delli Carpini Michael (2006) A New Engagement? Political Participation, Civic Life and the Changing American Citizen, Oxford/New York, OUP, 272 p. 


\section{Danièle Joly}

\section{Muslim Women's Political Engagement in British and French Society}

This article addresses the participation of women from Muslim communities in civic and political life in Britain and France against the backdrop of racism and discrimination. It establishes the key features of the societal frameworks which surround those women in the two countries since World War II and pays particular attention to dimensions informed by racism and anti-Muslim prejudice. It interrogates the interaction of the women with majority society, the obstacles and enablements they identify and the impact it may have on their participation in the public sphere, on their civic and political engagement.

\section{L'engagement politique des femmes de culture musulmane en France et en Grande-Bretagne}

Cet article a pour thème la participation des femmes de communautés musulmanes à la vie civique et politique en Grande-Bretagne et en France. II trace les contours du contexte sociétal dans lequel évoluent ces femmes dans les deux pays depuis la Deuxième Guerre mondiale, en accordant une attention particulière aux préjugés et aux différentes formes de racisme qu'elles doivent affronter. L'article examine l'interaction de ces femmes avec la société, les obstacles et facteurs facilitateurs qu'elles identifient et l'impact de ces derniers sur leurs aspirations à la participation civique et politique.

\section{El compromiso político de las mujeres musulmanas en Francia y Gran Bretaña}

Este articulo trata de la participación política y cívica de las mujeres de comunidades musulmanas. Plantea el contexto societal y político en los dos países desde la segunda guerra mundial, con una atención particular a los prejuicios y las distintas formas de racismo que estas mujeres deben enfrentar. El artículo examina la interacción de estas mujeres con la sociedad, los obstáculos y factores favorables que ellas identifican y su impacto hacia sus aspiraciones a la participación política y cívica. 